\title{
MEMAHAMI PANDANGAN EKOLOGI KORRIE LAYUN RAMPAN MELALUI TIGA CERITA PENDEK DALAM ANTOLOGI RIAM
}

\section{UNDERSTANDING KORRIE LAYUN RAMPAN'S ECOLOGICAL VIEW THROUGH THREE SHORT STORIES IN THE RIAM ANTOLOGY}

\author{
Aquari Mustikawati \\ Kantor Bahasa Provinsi Kalimantan Timur \\ Jalan Batu Cermin 25, Sempaja Utara, Samarinda \\ Pos-el: aquari.mustikawati@kemdikbud.go.id
}

*)Naskah diterima: 15 Oktober 2021; direvisi: 22 Oktober 2021; disetujui: 11 November 2021

\begin{abstract}
Abstrak
Penelitian ini mengungkapkan pandangan ekologi Korrie Layun Rampan sebagai pengarang tiga cerita pendek, yaitu "Teluk Par", Sungai Nyuatan", dan "Madu Lomuq" yang terdapat dalam Antologi Riam. Pandangan tersebut meliputi gambaran dan caracara hidup masyarakat yang berhubungan dengan alam. Masalah yang difokuskan dalam penelitian ini adalah bagaimana pandangan ekologi Korrie yang terdapat dalam ketiga cerita pendek tersebut? Metode kualitatif digunakan untuk memecahkan masalah, yaitu dengan cara mendeskripsikan gambaran alam dan cara-cara ekologi masyarakat dalam kehidupan mereka. Dengan menggunakan teori ekokritik sastra, tulisan ini menganalisis pandanganpandangan Korrie yang terbagi dalam kajian pastoral, apokaliptik, dan etika lingkungan. Hasil penelitian membuktikan terdapat kajian ekologi sastra yang ditemukan dalam ketiga cerita pendek tersebut. Dari hasil penelitian dapat disimpulkan bahwa Korrie Layun Rampan adalah pengarang yang memiliki konsep ekologi dalan karya-karyanya yang meliputi elemen pastoral, apokaliptik, dan etika lingkungan. Elemen pastoral yang terdapat dalam ketiga cerita pendek tersebut meliputi unsur bucholic atau gembala dan konstruksi arcadia yang menerangkan tentang deskripsi ideal suatu tempat tinggal dengan kenyamanannya.
\end{abstract}

Kata kunci: ekologi, cerpen, pastoral, apokaliptik

\begin{abstract}
This study reveals the ecological view of Korrie Layun Rampan as the author of three short stories, of "Teluk Par", Sungai Nyuatan", and "Madu Lomuq" from the Riam Anthology. These views include the description and ways of life of the community in relation to nature. The problem of this research is how Korrie's ecological views are contained in the three short stories? Qualitative methods are used to solve the problem, by describing the picture of nature and the ecological ways of society in their lives. Using literary ecocritic theory, this paper analyzes Korrie's views are divided into pastoral, apocalyptic, and environmental studies. The results of the research prove/show that there is a literary ecology study found in the three short stories. From the results of the study it can be concluded that Korrie Layun Rampan is an author who has an ecological concept in his works which includes pastoral, apocalyptic, and environmental ethics elements. Pastoral elements contained in the three short stories include bucholic or shepherd elements and archaic constructions which explain the ideal description of a place to live with its comfort.
\end{abstract}

Keywords: ecology, shorstories, pastoral, apocalyptic 


\section{PENDAHULUAN}

Kajian ekologi dalam karya sastra adalah penerapan ekologi dalam memandang sebuah karya sastra. Kajian ini marak dengan semakin banyaknya pengarang yang memasukkan usur alam ke dalam karya-karyanya. Bahkan, menurut Endraswara (2016:2), kajian ekologis sudah menjadi bagian dari sastra sejak zaman Plato. Konsep karya seni dan ide yang dituangkan Plato merujuk kepada keindahan alam semesta. Dalam pandangan Plato semua karya seni adalah tiruan aslinya. Hal itu berarti bahwa manusia menyadari akan keindahan alam yang ada di sekitarnya. Berdasarkan alasan tersebut, Endraswara berpendapat bahwa sangat perlu untuk mengabadikan keindahan dalam sebuah karya. Pendapat Endraswara tersebut menguatkan konsep ekologi yang terdapat dalam karya sastra. Seperti halnya pemikiran Plato, pengarang juga menganggap bahwa keindahan alam semesta perlu untuk dituangkan dalam sebuah karya sastra.

Selanjutnya, karya satra tidak lagi hanya menangkap tentang keindahan alam. Konsep ini berkembang dengan menyoroti kehidupan makhluk yang ada dalam lingkaran ekologi. Konsep ekologi sebenanrnya memiliki anggapan bahwa keberadaan organisme dipengaruhi oleh lingkungan di sekelilingnya. Hubungan tersebut bersifat timbal balik, yaitu keadaan suatu lingkungan dipengaruhi oleh keberadaan organisme yang ada di dalamnya. Sebagai bagian dari suatu ilmu pengetahuan, ekologi mengkaji hubungan organisme atau makhluk hidup dengan lingkungan tempat tinggalnya. Penerapan ekologi dalam karya sastra merupakan bentuk pendekatan ekologi dalam memandang sebuah karya sastra. Karya sastra tentang ekologi yang fenomenal dan mampu menarik perhartian manusiua pada zamannya adalah Silent Spring karya Rachel Carson. Buku ini yang menyoroti isu-isu lingkungan akibat penggunaan pestisida secara berlebihan di Amerika. Dalam bukuya, Carson dengan marah berusaha menyadarkan manusia akan dampak kerusakan alam yang ditimbulkan akibat penggunaan zat dalam pestisida yang dapat merugikan manusia, yaitu menimbulkan penyakit kanker. Garrard (2004:1) mengungkapkan bahwa buku ini mampu memelopori suatu gerakan tentang lingkungan modern. Gerakan lingkungan modern yang muncul tersebut menyoroti beberapa poin yang berhubungan dengan lingkungan, yaitu polusi lingkungan, musibah/bencana, kematian banyak hewan, dan dampak kesuburan tanah. Beberapa poin tersebut kemudian menjadi dasar dari kajian ekokritik.

Salah satu pengarang yang banyak menuangkan tema ekologi dalam karya-karyanya adalah Korrie Layun Rampan. Tematema alam dan budaya masyarakat Benuaq di Kalimantan Timur digambarkan dengan penuh kelokalan yang memberikan wawasan baru bagi pembaca akan kondisi alam Kalimantan, terutama hutan tropisnya. Keprihatinan Korrie sebagai bagian dari alam Kalimantan dituangkannya dalam setiap karyanya. Ia menyoroti permasalahan akibat pelaksanaan kebijakan terhadap hutan dan masyarakat lokal yang semena-mena seperti HPH (Hak Pengusahaan Hutan), perusakan alam akibat penambangan besar-besaran, dan penebangan pohon di hutan tanpa memikirkan kelestariannya. Isu-isu lingkungan tersebut selalu dituangkan Korrie dalam karya-karya tulisnya. Antologi Riam adalah salah satu kumpulan cerita pendek Korrie Layun Rampan yang memuat gambaran alam secara detail. Antologi ini oleh oleh pengarangnya terutama ditulis dengan tujuan untuk memperkaya khasanah sastra nasional yang berwarna lokal. Kelokalan tersebut terlihat dari penggambaran ciri Kalimantan secara detail, seperti sungai, hutan, dan dinamika masya- 
rakatnya. Kalimantan adalah suatu daerah dengan ribuan sungai. Hal itu memungkinkan masyarakatnya untuk berinteraksi dengan sungai sebagai lingkungan tempat tinggal mereka. Sungai merupakan sumber kehidupan masyarakat Kalimantan, yaitu sebagai sarana transportasi, sumber air, dan sumber makanan manusia. Oleh karena itu, keberadaan sungai sangatlah penting bagi masyarakat di sekitarnya. Kerusakan lingkungan yang berhubungan dengan sungai akan menimbulkan dampak yang sangat besar bagi manusia. Selain sungai, hutan juga merupakan bagian terpenting masyarakat Dayak yang tinggal di pedalaman. Hutan dan seisinya adalah sumber kehidupan mereka. Makanan yang berasal dari tanaman-tanaman hutan, hewan-hewan buruan, dan tanaman produksi untuk keperluan kehidupan mereka disediakan oleh hutan di Kalimantan.

Beberapa tulisan dan penelitian tentang ekokritik dalam karya-karya Korrie Rampan antara lain dirulis oleh Nina Queena Hadi Putri dkk, yang dimuat dalam Jurnal Satwika, tahun 2019. Nina menyoroti tentang kearifan lingkungan masyarakat Dayak Benuaq dalam Novel Api Awan Asap karya Korrie Layun Rampan. Novel ini mengisahkan kehidupan ideal, yaitu bersinerginya masyarakat dengan alam. Kerusakan alam yang terjadi di Desa Dempar disebabkan oleh ulah masyarakat pendatang yang melakukan eksploitasi alam. Sementara itu, penduduk lokal digambarkan memiliki perilaku ramah lingkungan yang disimpulkan oleh Nina dengan lima poin, yaitu telaah sikap hormat terhadap alam, sikap tanggung jawab terhadap alam, sikap solidaritas terhadap alam, sikap kasih sayang dan kepedulian terhadap alam, dan sikap tidak mengganggu kehidupan alam. Tulisan berikutnya tentang ekokritik dalam karya-karya Korrie Layun Rampan adalah sebuah sripsi yang ditulis oleh Ammar
Akbar Fauzi (2014). Skripsi ini menyoroti ekokritik Korrie Layun Rampan dalam Antologi Kayu Naga yang meliputi kerusakan alam akibat kebijakan Hak Pengusahaan Hutan (HPH) dan kebijakan izin mendirikan Hutan Tanaman Industri (HTI). Selain itu, antologi ini juga menjelaskan adanya mitos yang berkembang dalam masyarakat lokal tentang perusakan alam, yaitu hukuman bagi perusak alam dan adanya makhluk penjaga alam. Antologi Kayu Naga juga menyoroti kehidupan sosial masyarakatnya yang tidak terlepas dari alam.

Dalam kajian ilmu ekokritik, deskriptif variabel-variabel ekokritik dapat dibagi menjadi beberapa bagian model kajian untuk menjelaskan konsep ekologi dalam karya sastra. Model kajian tersebut adalah pastoral, apokaliptik, dan etika lingkungan. Berdasarkan beberapa uraian tersebut, tulisan ini memfokuskan pada bagaimana bentuk konsep ekologi yang dimiliki Korrie Layun Rampan dalam tiga cerpen bertemakan sungai yang terdapat dalam Antologi Riam melalui ketiga model kajian, yaitu pastoral, apokaliptik, dan etika liungkungan?

\section{LANDASAN TEORI}

Teori ekokritik sastra dikenal dengan munculnya kajian baru, yaitu yang disebut dengan Environmental Literary Criticism atau ekokritik sastra. Namun, kajian ini baru diakui secara akademis pada akhir abad ke-20 sebagai kajian akademis. Kajian ini bekerja dengan menelaah hubungan antara manusia dengan alam dan bagaimana hubungan manusia dengan alam. Peter Barry memopulerkan istilah ekokritik melalui bukunya Beginning Theory: An Introduction to Literary and Cultural Theory (1995). Namun, sebenarnya ekokritik sudah dikenal pada tahun 1978, ketika William Rueckert menulis sebuah esai yang berjudul "Literature and Ecology: An Experiment in "Eco-criticism". Dalam 
artikelnya, Rueckert mengungkapkan bahwa ekokritik adalah penerapan konsep ekologis dan sosial pada kajian sastra (Rueckert, 1978:107). Pada tahun 1996, Cheryll Glottfelty menerbitkan sebuah kumpulan esai pendekatan ekologis terhadap kajian sastra yang berjudul The Ecocritics Reader: Landmar$k s$ in Literary Ecology. Dalam bukunya tersebut, Glotfelty berpendapat bahwa ekokritik merupakan kajian tentang hubungan antara karya sastra dengan lingkungan fisik di sekitarnya (1996:xviii). Hal itu berarti bahwa mengkaji karya sastra dengan pendekatan teori ekokritik adalah menggabungkan dua teori yang berbeda, yaitu ekologi dan sastra. Dengan rendah hati, Garrad (2004:5) mengemukakan bahwa ekokritik mungkin tidak memiliki kewenangan dalam perdebatan di bidang ekologi, tetapi paling tidak memiliki litersai ekologinya sendiri yang dapat memberikan bahan tentang ancaman lingkungan bagi para ekokritik.

Karya sastra yang dianggap berorientasi lingkungan mempunyai satu dari empat kriteria (Sukmawan, 2016:48). Keempat kriteria tersebut adalah menunjukkan bahwa sejarah manusia terlibat dalam sejarah alam; kepentingan manusia tidak dipahami sebagai satu-satunya kepentingan yang sah; pentingnya pertanggungjawaban manusia terhadap lingkungan yang merupakan bagian dari orientasi etis teks; dan lingkungan sebagai suatu proses, bukan sebagai sesuatu yang konstan atau yang diberikan (Buell, 1995:7).

Variabel-variabel dalam karya sastra yang dapat dianggap sebagai bagian dari ekokritik menurut para pakar ekokritik adalah pastoral yang meliputi bucholic yang memiliki arti harfiah pengembala dan konstruksi arcadia yang meliputi idylls, deskripsi ideal desa, nostalgia, dan georgic yang dapat diartikan kenyamanan dan ketenangan bekerja. (Sukmawan, 2016:49). Secara umum, bucholic dapat diartikan seba- gai karakter polos dan asli. Sementara itu, konsep arcadia dapat diartikan sebagai konsep hidup ideal. Variabel lainnya adalah apokaliptik, yaitu bercirikan karakter pahlawan atau sosok tokoh yang memiliki visi terhadap alam (Sukmawan, 2016:97). Variabel yan terakhir adalah etika lingkungan yang memiliki dua pengertian, yaitu ajaran kehidupan alam dan sikap kritis manusia dalam menghadapi kerusakan alam (Sukmawan, 2016:184--185). Istilah etika lingkungan dapat diartikan sebagai kearifan lingkungan. Amrih (2008:33) mengatakan bahwa kesadaran akan menjadi bagian dari alam dan membantu terciptanya kesatuan harmoni dinamakan kearifan lingkungan. Menurut Sukmawan (2016:20), ada tiga prinsip dalam etika lingkungan, yaitu pengetahuan atau praktik sebagai hasil dari refleksi manusia dengan alam, kerifan lokal dan manusia memiliki bubungan yang erat, dan adanya permasalahan lingkungan menadakan hubungan manusia dengan alam sedang tidak harmonis.

\section{METODE PENELITIAN}

Metode yang digunakan dalam kajian ini adalah kualitatif, yaitu metode yang lebih memerhatikan data alamiah (Ratna, 2008:47). Data tersebut digunakan untuk mengaitkan sejumlah gejala sosial yang relevan, termasuk unsur-unsur kebudayaan dan lingkungan. Sementara itu, pendekatan yang digunakan untuk mengolah data adalah pendekatan ekologi sastra. Ekologi sastra adalah ilmu ekstrinsik sastra yang mendalami hubungan sastra dengan lingkungan sekitarnya (Endraswara, 2016:5). Berdasarkan pendapat Endraswara dapat diartikan bahwa ekologi sastra adalah ilmu di luar sastra yang dijadikan rujukan karena hubungannya dengan alam. Melalui ilmu ekologi, sastra dapat mengungkap suatu peristiwa yang melibatkan lingkungan sekitar sebagai objek kajiannya (Sugiarti, 2017:111). 
Data kajian ini adalah tiga cerita pendek Korrie Layun Rampan yang terdapat dalam Antologi Riam. Pengolahan data-data tersebut dilakukan dengan cara-cara sebagai berikut (1) menentukan sumber atau data primer yang berhubungan dengan ekokritik sastra, (2) selanjutnya adalah identifikasi data, yaitu penentuan kajian analisis pastoral, apokaliptik, dan etika lingkungan (3) analisis data dengan menggunakan teori ekokritik dan pendekatan ekologi sastra, dan (4) menyimpulkan konsep ekologi pengarang.

\section{HASIL DAN PEMBAHASAN}

Tiga cerita pendek dalam Antologi Riam yang menjadi obyek kajian kali ini adalah "Teluk Par", "Sungai Nyuatan”, dan "Madu Lomuq". Ketiganya memiliki karakter khas suatu teks yang memiliki kearifan lingkungan, yaitu mencakup beberapa konsep kajian ekokritik. Aktivitas dan perilaku manusia terhadap alam menjadi penyebab utama perubahan keseimbangan alam. Anggapan egosentris yang memandang manusia sebagai makhluk utama telah melupakan adanya kehidupan masa depan bagi anak cucu. Keadaan tersebut dituangkan Korrie secara eksplisit dan implisit dalam ketiga cerita pendek tersebut.

\section{Kajian Pastoral}

Kajian Pastoral meliputi narasi tentang alam pedesaan yang kontras dengan perkotaan. Kajian ini terbagi menjadi dua, yaitu bucholic dan arkadia. Bucholic atau pengembala menggambarkan mata pencaharian khas yang berhubungan dengan alam. Sementara itu, arkadia meliputi tiga narasi, yaitu idylls (deskripsi ideal desa), nostalgia, georgic (kenyamanan dan ketenangan bekerja.

Narasi bucholic terdapat dalam cerita "Sungai Nyuatan", yaitu tentang salah satu cara mencari nafkah di Sungai Nyuatan dengan menangkap buaya. Sungai-sungai di pedalaman Kalimantan memiliki aneka ragam satwa penghuninya. Salah satu yang dapat menghasilkan uang cukup banyak adalah buaya. Kulit buaya dihargai cukup mahal di pasaran. Dengan alasan itu masyarakat yang hidup di sekitar sungai berusaha menangkap buaya untuk mendapatkan kulitnya. Meskipun usaha menangkap buaya tidaklah mudah, dengan berbekal pengalaman beberapa orang berusaha untuk melakukannya.

Ke bawah kampar kayu itu, buaya membawa tali pancing yang diikatkan pada sebatang pohon rotan panjang yang mengapung di arus sungai. Di sebelah Teluk Nyomit ke arah hulunya sedikit, pancing buaya yang dipasang dengan umpan seekor anak kera yang sudah mati tampak mengapung di arus sungai (Rampan, 2001:12).

Kutipan tersebut secara umum menjelaskan salah satu mata pencaharian masyarakat di sekitar Sungai Nyuatan, yaitu menangkap buaya. Cara-cara menangkap buaya dijelaskan Korrie dengan detail, yaitu menggunakan umpan hewan yang sudah mati yang diikatkan pada rotan yang panjang. Alat yang digunakan menangkap buaya tersebut menggunakann sumber daya yang ada di sekitar Sungai Nyuatan. Berdasarkan beberapa hal tersebut, penangkapan buaya yang diceritakan dalam cerita pendek "Sungai Nyuatan " ini terlihat sangat lokal. Masyarakat Benuaq, seperti halnya masyarakat lainnya yang hidup di daerah hulu atau pedalaman Kalimantan dikenal sangat memahami kehidupan alam mereka. Mereka bahkan hidup berdampingan dengan alam. Bagi mereka alam adalah kehidupan mereka. Hal itu menunjukkan bahwa masyarakat Benuaq telah mampu menciptakan budaya yang berhubungan dengan ekosistem mereka. Mereka mengambil makanan dari alam, 
yaitu dari hasil tanaman, hasil air atau sungai, dan juga hewan-hewan yang hidup di hutan. Sebagai tambahan Djuweng dalam Pudentia menjelaskan bahwa masyarakat Dayak mengetahui cara-cara pemanfaatan sumber daya alam yang berkesinambungan. Mereka mengetahui nama dan manfaat tumbuh-tumbuhan, memiliki ratusan bibit padi, mengetahui nama semua binatang dan perilaku-perilakunya (2008:169). Secara khusus, kutipan tersebut menjelaskan bahwa menangkap buaya sebagai mata pencaharian bukanlah pekerjaan yang mudah. Pekerjaan tersebut sangat berat dan beresiko. Menangkap buaya memerlukan kekuatan dan ketrampilan tertentu yang tidak semua orang dapat melakukannya.

\begin{abstract}
Kakakku yang sudah pernah dua kali mengail buaya di sungai itu, tentu tahu bahwa buaya yang terlanjur menelan umpan akan dengan mudah ditarik ke atas permukaan air. Pada saat ia berada di permukaan itulah pemancing harus hati-hati, karena dengan bagian ekornya yang biasa untuk menjatuhkan kera atau bekantan, ia dapat memukul dengan keras. Banyak kisah menyebutkan bahwa tak jarang babi, kambing, atau anak sapi, hanya dengan sekali pukul akan roboh ke sungai, dan buaya yang lapar segera melahapnya (Rampan, 2001:13).
\end{abstract}

Gambaran sulitnya melakukan pekerjaan menangkap buaya tersebut menunjukkan bahwa pekerjaan ini tidaklah mudah. Tingang, kakak tokoh dalam cerita pendek ini digambarkan sebagai seorang yang tangguh yang sudah berpengalaman dalam menangkap buaya. Tentu saja ia tahu cara memancing buaya dan menangkapnya dengan menggunakan alat-alat yang dapat dicari di alam sekitarnya. Karakter bucholic dalam cerita "Sungai Nyuatan" ini merupakan suatu kekhasan yang ada di daerah tersebut. Gambaran tersebut menguatkan kemahiran masyarakat Benuaq dalam ber- buru buaya di sungai-sungai di pedalaman Kalimantan.

Karakteristik bucholic juga terdapat dalam cerita pendek "Madu Lomuq". Hal ini berhubungan dengan mata pencaharian sebagai pencari madu di pohon tanyut dan lomuq. Masyarakat Benuaq memiliki suatu kearifan lokal, yaitu menanam beberapa pohon tanyut dan lomuq sebagai bagian dari mata pencaharian mereka. Pohon tanyut dan lomuq adalah pohon yang sangat tinggi dan sangat disukai tawon untuk membuat sarang di pangkal batangnya. Oleh karena itu, masyarakat Benuaq di pedalaman sengaja menanam dan memelihara kedua jenis pohon tersebut. Mereka menganggap menanam pohon-pohon jenis tersebut sebagai investasi apabila terdapat sarang tawon yang banyak bergelantungan di pangkal pohonnya.

Namun, Rayuwa tetap juga memelihara
sejumlah pohon tanyut puti dan lomuq,
karena hal itu merupakan gengsi....
namun hanya satu lomuq yang selalu
digandrungi tawon untuk meletakkan
sarang. Meskipun pohon lomuq itu masih
muda, sekitar berusia seratus tahun....,
pohon itu kadang dihinggapi seratus
saf sarang madu, Jika setiap sarang
mengandung masing-masing satu
kilogram madu berikut tempayak dan
lilin, sebenarnya lumayan juga (Rampan,
2001:66--67).

Kutipan tersebut dengan jelas menggambarkan pendapatan dari memiliki pohon tanyut dan lomuq yang dihinggapi sarang tawon. Memiliki pohon-pohon tersebut dapat dikatakan memiliki penghasilan yang lumayan besar, sehingga tidaklah mengherankan apabila masyarakat di pedalaman berusaha mendapatkan dan memelihara pohon tanyut dan lomuq yang dapat menghasilkan pendapatan bagi mereka. 
Sementara itu, proses pengambilan sarang-sarang tawon tersebut juga merupakan suatu kearifan lokal tersendiri. Pohon tanyut lomuq dikenal sebagai pohon yang tinggi sehingga memerlukan ketrampilan memanjat yang mahir. Proses pengambilannya juga memerlukan persiapan berupa alat-alat memanjat dan sumber daya manusia yang memiliki pengalaman dalam pengambilan sarang tawon. Korrie menjelaskan dalam cerpen "Madu Lomuq" secara terperinci proses pengambilan sarang tawon yang tidak mudah tersebut.

\begin{abstract}
Pernah kudengar dari kawanku Terokok Udok bahwa memanjat madu harus dilakukan di malam hari dan para pemanjatnya adalah orang-orang gagah berani karena mnmanjat madu memiliki resiko yang sangat tinggi. Selain sengatan tawonnya sangat sakit, seperti ditusuk jarum suntuk yang majal, juga kalau angin datang, pohon tanyut yang tinggi akan bergoyang menakutkan (Rampan, 2001:66).
\end{abstract}

Karakter bucholic tergambar dalam ritual pengambilan madu dari pohon tanyut lomuq, yaitu melalui pemiliknya yang berusaha tetap melestarikan jenis pohon tersebut yang ternyata memiliki nilai tinggi. Selain, hasil berupa madu, terkadang pohon jenis tersebut hidup di lahan rotan yang juga menghasilkan nilai jual tinggi, seperti yang tergambar dari kutipan berikut ini. Apalagi kalau tanyut madu itu di lingkungan rotan yang berharga, harga rotan yang harus dibersihkan jauh lebih banyak dari harga tempayak madu atau lilin dan air madunya (Rampan, 2001:66). Kutipan tersebut menerangkan bahwa tanaman tanyut selain dapat menjadi rumah bagi sarang tawon juga tumbuh di satu tempat dengan tanaman rotan yang juga memiliki nilai jual tinggi. Berdasarakan alasan tersebut, tanaman komoditas seperti tanaman tanyut patut dilestarikan dan apabila perlu diperbanyak sehingga menghasilkan produksi yang memberikan manfaat bagi masyarakat sekitarnya.

Kajian pastoral juga memiliki karakteristik lainnya, yaitu konstruksi arcadia yang terdiri atas idylls (deskripsi ideal desa), nostalgia, dan georgic (kenyamanan dan ketenangan bekerja). Konstruksi arcadia dapat diartikan juga cara hidup atau tempat yang diidealkan (Sukmawan, 2016:49). Secara umum, karya sastra yang meliputi konsep pastoral merupakan karya yang mendeskripsikan keadaan pedesaan yang dikontraskan secara implisit dan eksplisit dengan kota. Hal itu berarti bahwa konsep pastoral mengidealkan kehidupan pedesaan yang tenang dan dekat dengan alam.

Konstruksi arcadia tersebut banyak ditemui dalam cerita "Sungai Nyuatan", yaitu berupa unsur nostalgia. Cerita pendek ini mengisahkan kembalinya seorang warga asli ke kampung halamannya setelah empat puluh tahun berada di kota. Pada saat ia kembali keadaan kampungnya sudah banyak berubah, keadaan alamnya sudah banyak yang rusak. Ia hanya bisa bernostalgia tentang keindahan alam pada masa kanak-kanaknya. Salah satu kutipan unsur nostalgia adalah sebagai berikut.

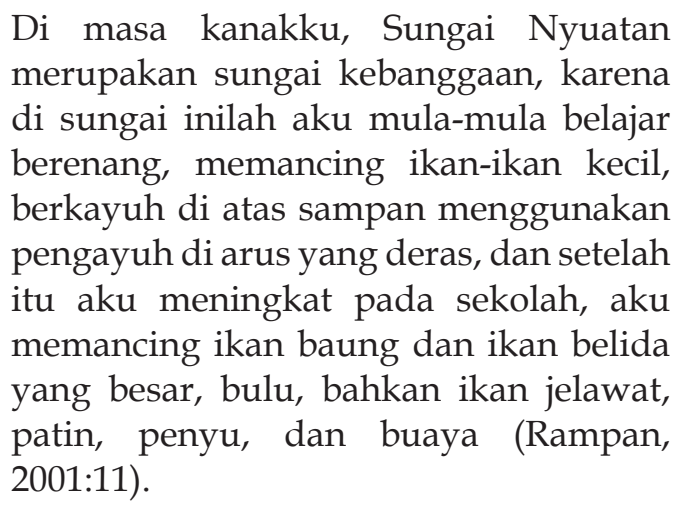

Nostalgia adalah elemen dasar arcadia (Sukmawan, 2016:37). Ciri konsep pastoral ini adalah selalu melihat ke masa lalu yang ideal dan membandingkannya dengan masa sekarang. Substansi unsur nostalgia adalah kerinduan akan kenangan masa si- 
lam yang indah yang tidak didapat lagi pada masa sekarang. Hal ini sangat berkaiatan dengan masa sekarang yang memiliki keadaaan yang berbeda.

Tokoh Aku dalam "Sungai Nyuatan" bernostalgia akan masa kanak-kanaknya yang indah di Sungai Nyuatan. Kenangan tersebut tidak dapat diulang kembali karena keadaan Sungai Nyuatan saat ini sudah berubah keadaan alamnya. Perubahan alam tersebut diterangkan oleh Korrie sebagai suatu kerugian alam dan spiritual. Kerugian alam ditandai dengan hilangnya pohon-pohon di sekitar sungai yang memperkaya ekologi sungai, seperti yang terungkap dalam kutipan berikut ini.

Pohon-pohon rengas yang dahulu sering digayuti madu, tak lagi tampak merimbakan bantaran sungai....Pohon-pohon raksasa zaman lampau seakan-akan diangkat oleh angin puting beliung, hilang diterbangkan ke negeri awan (Rampan, 2001:16).

Jejak nostalgia dalam cerita "Sungai Nyuatan" mengarahkan pandangan ke belakang, yaitu ke masa lalu agar selalu mengingat kehidupan dahulu yang ideal. Dengan mengingat kehidupan ideal manusia dapat berangan-angan untuk meraih kembali kehidupan tersebut. Mereka akan termotivasi untuk berusaha meraih kehidupan yang didealkan. Nostalgia akan menjadi pandangan dalam mewujudkan kehidupan ideal dengan alam.

Elemen nostalgia juga terdapat dalan cerita "Teluk Par", yaitu berupa cerita masa lalu yang mengisahkan sejarah tempat bernama Teluk Par. Keagungan sejarah suatu tempat menjadi kebanggaan tersendiri yang patut dikenang bahwa pada masa dahulu masyarakat di sekitar daerah tersebut pernah mengalami kejayaan. Selain itu, sejarah yang besar tersebut dapat menjadi pengingat suatu tempat, walaupun kemudian hari tempat tersebut tidak ada lagi.
Kata orang di teluk itu di zaman ngayau pernah terjadi pertetmpuran hebat, sehingga harus dibuatkan tanda sebagai peringatan bahwa musuh dengan susah payah mampu dipukul mundur; terutama atas kekuatan Panglima Maliangsa Posa, Pendekar dari Negeri Bulan Bersinar ini hanya menggunakan senjata jembia, mampu memukul mundur pasukan artileri yang dipimpin Panglima Kode Bekelataq (Rampan, 2001:2).

Jenis nostalgia pada cerita "Teluk Par" menggambarkan sejarah Teluk Par yang pernah menjadi ajang pertempuran antara dua suku pada zaman dahulu. Tanda yang diletakkan di daerah tersebut untuk mengingatkan masyarakat pada masa sekarang bahwa pada masa dahulu pernah terjadi pertempurang ngayau antara dua pihak dengan gagah berani. Selain mengenang peristiwa ngayau pada zaman dahulu, tanda tersebut juga dianggap sebagai tanda untuk menutupi adanya tambang emas di bawahnya. Menurut dugaan mungkin orang Belanda yang menancapkan tanda itu di situ, karena tempat itu tersimpan tambang emas yang depositnya sangat besar (Rampan, 2001:3).

Berdasarkan cerita tersebut, masyarakat mulai menganggap tempat itu sebagai tempat yang disakralkan. Mereka tidak berani berbuat sembarangan di tempat tersebut. Bahkan mereka menganggap tempat tersebut sebagai tempat yang angker. Beberapa cerita tabu yang dilanggar di tempat tersebut mengakibatkan masalah bagi pelanggar walaupun secara logika tidak beralasan. Seperti misalnya, sebuah keluarga yang mencoba berhuma di tempat tersebut, mendapai anaknya hamil. Masyarakat percaya bahwa hantu-hantu panglima yang menghamili anak gadis tersebut. Namun, setelah diperiksa dokter, gadis tersebut hamil saudara kembarnya sendiri dan bukan karena berhubungan badan (Rampan, 2001:5).

Cerita sejarah ditambah dengan menganggap angker Teluk Par menjadikan ma- 
nusia berhati-hati dalam berperilaku di Teluk Par. Namun, sebetulnya mitos yang berkembang tersebut melindungi ekosistem yang ada di daerah tersebut. Masyarakat tidak mudah melakukan eksploitasi alam di sana. Apalagi ternyata Teluk Par termasuk jalur sungai yang cukup berbahaya seperti yang tergambar dalam kutipan berikut ini.

\begin{abstract}
Nah, kini jika kau berangkat dari Damai atau dari Kampung Besiq menuju Rinding dengan menggunakan ketinting, kau harus hati-hati jika sampai pada suatu rantau yang berlekuk dengan arus yang deras. Kau harus benar-benar siaga, karena Teluk Par membentuk sebuah teluk patah yang kadang membuat ketinting oleng dan kemudian karam (Rampan, 2001:5).
\end{abstract}

Jadi sebetulnya elemen nostalgia yang merupakan cerita masa lampau tentang kejadian yang pernah terjadi di Teluk Par menimbulkan mitos akan keangkeran tempat tersebut. Masyarakat tidak berani untuk berlaku sembarang di tempat tersebut. Keadaan ini menjadikan ekosistem di Teluk Par terjaga. Mereka membiarkan keadaaan alam Teluk Par seperti masa dahulu dan tidak berani mengubahnya.

Elemen lainnya dalam unsur arcadia adalah idylls yang berarti deskripsi ideal tentang desa atau alam. Deskripsi ini dapat ditemukan dalam cerita "Teluk Par" yang menggambarkan keunikan pohon tinggi tempat sarang madu.

Ia akan menunjuk ke arah sebuah pohon tinggi yang oleh warga di situ disebut rinikng! Jika musim madu membangun sarang, dahan-dahan pohon rinikng itu tampak unik, karena memiliki panorama yang melegam, sebab ratusan sarang madu bergelantungan di dahan-dahan yang lampai lagi besar dan kukuh itu (Rampan, 2001:4).
Pemandangan alam yang eksotis dan unik tentang keharmonisan kehidupan manusia, tumbuhan, dan hewan disatukan dalam gambaran ideal sarang tawon di pohon rinikng. Selain memperlihatkan kehidupan harmonis alam, gambaran tersebut juga menunjukkan kemakmuran atau kesejahteraan karena sarang-sarang tawon tersebut bernilai sangat tinggi. Setelah diambil sarangnya, tawon-tawon tersebut akan membuat sarang mereka lagi pada musim madu, sehingga masyarakat tidak perlu takut untuk kehabisan sarang tawon.

Elemen terakhir dam unsur arcadia adalah georgic yang menggambarkan kenyamanan dan ketenangan bekerja. Elemen ini dapat ditemukan dalam cerita "Sungai Nyuatan", yaitu mengambarkan detail pekerjaan yang ditampilkan secara harmonis dengan alam. Penangkapan buaya dalam "Sungai Nyuatan" digambarkan secara terinci, yaitu menggunakan alat-alat yang berasal dari alam.
Akan tetapi, kakakku sungguh anak lelaki. Tak sedikitpun ia tampak gugup atau gentar, ia terus menarik tali rotan, sehingga jarak antara buaya dan dirirnya semakin dekat. Sesekali buaya berusaha memukul ekornya ke arah sampan, tapi kakakku dengan sigap menahan dengan bilahan dayung (Rampan, 2001:14).

Pekerjaan menangkap buaya memang beresiko, tetapi hubungannya dengan alam, pekerjaan ini termasuk bagian dari keharmonisan alam. Penangkapan buaya yang dilakukan dengan cara-cara tradisional dan menggunakan alat-alat yang ada di alam merupakan bagian dari pengendalian ekosistem. Selain itu, dalam penangkapan buaya secara tradisional tersebut hanya dapat menangkap seekor buaya dalam sekali kegiatan penangkapan. Hal itu berarti kegiatan penangkapan buaya secara tradisional tidak termasuk dari eksploitasi alam. 
Elemen georgic ini juga dapat ditemukan dalam cerita "Madu Lomuq" yang menceritakan cara-cara dalam pengambilan madu dari atas pohon. Seperti halnya, penangkapan buaya dalam cerita "Sungai Nyuatan", pengambilan madu di pohon tingga juga penuh resiko, tetapi cara-cara yang digambarkan dalam pengambilan madu tersebut sangat berpihak pada alam. Berikut ini kutipannya.

Pemanjat akan segera mengambil uyukng, tempat menurunkan sarang dan air madu. Kuperhatikan para penyambut harus gesit bertarung dengan tawon-tawon yang berkeliaran mencari sarangnya yang hilang. Mereka sangat sibuk selain harus hati-hati berjalan di kawasan tanah yang kotor dan berduri, juga harus menepis dan mengibaskan tawon yang mennyengat. Sementara uyukng yang berisi air dan tempayak madu harus segera disambut, lalu dipindahkan ke tempat khusus yang sudah disediakan agak jauh dari bawah pohon lomuq (Rampan, 2001:68).

Kutipan tersebut cukup menjelaskan bagaimana para pengambil madu yang terdiri atas pemanjat dan penyambut yang berada di bawah pohon bekerja sama untuk menyelesaikan tugas melawan tawon-tawon yang terusik. Proses kerja tersebut merupakan bagian dari keharmonisan alam. Para pengambil sarang tawon tersebut memahami caracara meminimalisasi serbuan tawon. Mereka sama sekali tidak menggunakan cara-cara yang merusak alam. Selain itu, dibutuhkan ketrampilan tinggi dalam pengambilan madu. Pemanjatan itu merupakan hal yang sangat berharga bagiku, seperti bagaimana proses memasang ngayan, meletakkan kelah, menarik dan menurunkan uyukng, serta cara yang benar mendaki di atas dahan pohon yang tinggi (Rampan, 2001:69). Cara-cara berinteraksi dengan alam berhubungan dengan pekerjaan atau mata pencaharian merupakan bagian dari dinamika masyarakat yang termasuk bagian dari kebudayaan. Dua konsep sentral dalam ekologi budaya adalah lingkungan dan adaptasi (Kaplan dan Manners, 2012:104). Dalam teori yang mencermati bagaimana manusia merespon lingkungan untuk menjaga kelangsungan hidupnya. Elemen georgic yang mengisahkan dinamika penangkapan buaya dan pencarian madu di pohon yang yang tinggi merupakan bagian dari kehidupan masyarakat yang selaras dengan alam.

\section{Kajian Apokaliptik}

Sastra apokaliptik menurut Sukmawan (2016:77) adalah salah satu jenis sastra kearifan lingkungan yang berciri khas adanya penarasian sejarah alam, tokoh pahlawan yang bervisi alam, dan keajaiban alam. Kajian ini meliputi unsur kepahlawanan yang ditonjolkan dalam suatu cerita. Ciri khas apokaliptik yang dapat ditemukan dalam ketiga cerita pendek dalam Antologi Riam adalah karakter pahlawan dan visi atau ramalan.

Karakter pahlawan yang terdapat dalam cerita "Sungai Nyuatan" dapat dijumpai pada tokoh kakak, yaitu Tingang. Tokoh Tingang digambarkan sebagai seorang anak laki-laki yang hidup dan akrab dengan alam. Kepandaiannya dalam menaklukkan alam termasuk menangkap buaya merupakan suatu kelebihan sebagai seorang anak berumur dua belas tahun.

\footnotetext{
Sebagai anak-anak yang menurut ukuran orang kota masih terlalu hijau dan tak mungkin punya keberanian untuk menangkap buaya yang panjangnya lebih dari tiga meter, ternyat kakakku telah menjadi pahlawan. Usianya belum du belas tahun telah membawanya pada pengalaman keberanian yang menyabung nyawa. (Rampan, 2001:13).
}

Sosok Tingang dianggap pahlawan oleh tokoh Aku dalam cerita "Sungai Nyuatan". Sifatnya yang berani dan terampil dalam mengemudikan sampan dan yang paling 
penting adalah tokoh yang dianggap memiliki kemampuan lebih dalam bergumul dengan alam. Dengan alasan-alasan tersebut, sosok Tingang memiliki potensi sebagai tokoh pahlawan. Selain keberaniannya, Tingang juga memiliki visi yang berpihak kepada alam. Dalam menangkap buaya, Tingang mengandalkan rotan sebagai tali penarik buaya dan tali untuk mengikat mulut buaya.

Elemen ramalan juga terdapat dalam cerita "Sungai Nyuatan" pada saat itu tokoh Tingang memberikan pandangannnya terhadap keadaan alam dan aktivitas menangkap buaya yang dilakukannya dengan adiknya. Pandangannya tersebut mengandung ramalan akan keadaan alam pada masa datang. Berikut ini kutipan yang menjelaskan ramalan tersebut.

\section{"Pada suatu masa," katanya, "tidak akan ditemukan orang memancing buaya karena sungai ini akan kehilangan bina- tang air yang buas itu."....Bahkan pohon nangka air yang buahnya menjadi umpan memancing ikan baung dan ikan jelawat, ikut terimbas sebagai kenang-kenangan yang melajur bagaikan mimpi yan terhapus tanpa bekas (Rampan, 2001:16).}

Pengalaman Tingang sebagai se-orang anak yang akrab dengan alam mengajarkannya untuk menikmati alam selagi masih ada. Ia memahami perubahan keadaan alam yang semakin lama semakin rusak yang disebabkan oleh perubahan alam dan campur tangan manusia.

\section{Etika Lingkungan}

Sikap-sikap yang menunjukkan bagian dari etika lingkungan adalah sikap hormat, tanggung jawab, kepedulian, solidaritas, dan tidak mengganggu atau merusak alam. Etika lingkungan dalan cerita "Teluk Par" terlihat dari dimunculkannya mitos tentang cerita-cerita angker di daerah tersebut. Mitos tersebut menyebabkan ma- nusia tidak berani lagi untuk mengganggu alam di daerah tersebut. Kenyatannya, daerah Teluk Par sangat kaya akan ekologinya, yaitu sarang-sarang tawon yang dapat memberikan hasil yang tidak sedikit dan sumber hayati yang mampu memberikan pendapatan nasyarakat. Selain itu, terdapat cerita adanya tambang emas di dalamnya. Namun, masyarakat lebih memilih memercayai mitos dan tidak mengganggu alam di Teluk Par.

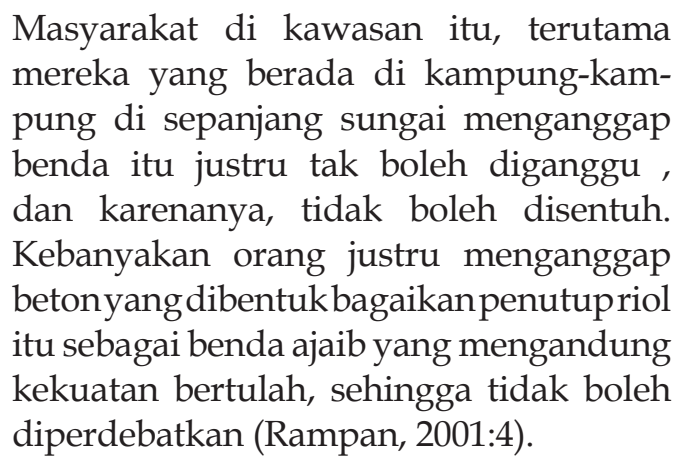

Kutipan tersebut menjelaskan bahwa masyarakat di sekitar Teluk Par tidak berani menganggu tanda yang dibuat untuk menandai tempat bersejarah. Wujud kepedulian mereka terhadap alam ditunjukkan dengan tidak mengganggu dan merusak ekosistem di Teluk Par. Salah satu sebabnya adalah mereka menganggap tempat tersebut sebagai tempat yang sakral dan perlu dilindungi. Mitos tersebut menjadikan ekosistem di daerah tersebut terjaga dan kehidupan makhluk-makhluk di lingkungan tersebut dapat terlindungi dan berkembang dengan baik.

Kepercayaan masyarakat lokal terhadap cerita sejarah tempat tersebut menciptakan suatu pemahaman akan adanya tragedi atau karma yang terjadi apabila tempat tersebut diusik. Mereka meyakini bahwa nasib jelek yang akan didapat apabila mereka merusak ekosisitem di Teluk Par.

\footnotetext{
"Apa nanti tidak habis uang hasil ganti rugi kalau roh-roh marah? Kalau
} 
misalnya terkena bencana? Luka, patah kaki, muncul bisul di pantat atau di dahi, atau terkena impotensi (Rampan, 2001:4).

Namun, ketika uang mulai menguasai sebagian masyarakat, mereka tidak dapat lagi mengontrol perilaku mereka terhadap alam. Mereka tidak lagi menghiraukan karma dan kelestarian alam Teluk Par akibat mengganggu ekosistem di sana. Bahkan, masyarakat mulai meminta kompensasi seakan-akan mereka dulunya menjadi pemilik Teluk Par.

\begin{abstract}
"Bayar harga tanah kami! bayar harga tanah kami! jangan main gusur sembarangan! Jangan seperti Orde Baru yang main gusur dan sikat tanpa adat! Mana pimpinan? Bayar dulu harga tanah kami!" (Rampan, 2001:8).
\end{abstract}

Teluk Par sebagai kawasan yang seharusnya dijaga ekosistemnya rusak oleh proyek jembatan yang justru diprakarsai oleh anak ketua adat mereka yang sudah menjadi bupati. Bahkan, masyarakatnya yang mengetahui hal tersebut tiba-tiba merasa berhak atas tanah tersebut.

Kearifan lingkungan juga dapat ditemukan dalam cerita "Madu Lomuq". Proses yang ditunjukkan para pencari madu dalam pengambilam madu memperlihatkan tolerasi dan tanggung jawab akan alam. Sarang-sarang tawon yang bergelantungan di pokok-pokok pohon tinggi tanyut dan lomuq diambil dengan proses yang sama sekali tidak merusak alam. Para pencari madu yang terdiri atas pemanjat pohon dan penadah sarang yang berada di bawah pohon memilih tidak merusak alam, yaitu dengan tidak mengambil madu dengan memotong pohonnya, tetapi mereka mengambil dengan cara memanjat yang beresiko mendapat sengatan tawon. Untuk menyiasati hal tersebut mereka melakukannya di malam hari. Tentu saja, proses pengambilam sarang tawon di malam hari tidaklah mudah, tetapi mereka menghindari cahaya yang dapat membuat tawon lebih ganas.

\begin{abstract}
Pernah kudengar dari kawanku Terokok Udok bahwa memanjat madu harus dilakukan di malam hari dan paora pemanjatnya adalah orang-orang gagah berani karena memanjat madu memliki resiko yang sangat tinggi (Rampan, 2001:8).
\end{abstract}

Etika lingkungan yang ditemukan dalam cerita, yaitu "Teluk Par" dan "Madu Lomuq" meliputi kegiatan kearifan lingkungan menjaga alam dan ekosistemnya yang memiliki kekayaan alam dan kegaiatan pengambilan madu yang berlandaskan tanggung jawab akan kelestarian alam, terutama pohon tinggi seperti tanyut dan lomuq yang biasanya dihinggapi sarang tawon.

\section{PENUTUP}

Konsep ekologi Korrie Layun Rampan dalam ketiga cerita pendeknya, yaitu "Sungai Nyuatan", "Teluk Par", dan "Madu Lomuq" meliputi kajian pastoral, kajian apokaliptik, dan Etika Lingkungan.

Kajian pastoral yang meliputi narasi bucholic atau pengembala dapat ditemukan dalam cerita "Sungai Nyuatan" dan "Madu Lomuq". Dalam "Sungai Nyuatan" narasi bucholic ditemukan dalam mata pencaharian, yaitu menangkap buaya. Mata pencaharian menangkap buaya sangatlah lokal dan hanya ditemui di beberapa tempat yang penduduknya tinggal di sekitar sungai seperti Sungai Nyuatan. Dalam cerita pendeknya diceritakan bahwa pekerjaan tersebut adalah pekerjaan berat yang berisiko tinggi. Narasi bucholic lainnya terdapat dalan cerita "Madu Lomuq" yang menggambarkan suatu pekerjaan sebagai pencari madu di pohon-pohon yang tinggi. Pekerjaan tersebut dilakukan oleh lebih dari satu orang, yaitu pemanjat pohon dan penadah di bawah pohon. Pekerjaan ini juga memer- 
lukan keahlian khusus, terutama memanjat pohon yang tinggi dan kekompakan dengan penadah di bawah. Narasi bucholic dalam dua cerita tersebut sengaja ditonjolkan Korrie sebagai bagian dari kelokalan masyarakat Benuaq.

Kajian pastoral juga meliputi konstruksi arcadia yang termasuk di dalamnya narasi idylls atau deskripsi ideal sutau desa atau alam. Gambaran tersebut dapat ditemukan dalam cerita "Teluk Par" yang mengungkapkan keindahan sarang-sarang tawon bergelantungan di pokok pohon. Dalam konstruksi arcadia juga terdapat elemen nostalgia, yang dapat ditemukan dalam cerita "Sungai Nyuatan" dan "Teluk Par". Elemen nostalgia dalam "Sungai Nyuatan" membandingkan keadaan alam masa dahulu dengan masa sekarang. Sementara itu, elemen nostalgia dalam "Teluk Par" berupa cerita sejarah masa lampau tentang kegagahan para pendekar pahlawan dalam menghadapai musuh. Elemen terakhir dalam konstruksi arcadia adalah georgic yang berupa kegiatan mencari nafkah di alam pedesaan. Elemen tersebut dapat ditemukan dalam "Sungai Nyuatan" yang mengungkapkan dengan detail cara-cara menangkap buaya dengan peralatan yang terdapat di alam. Sementara itu, elemen georgic juga dapat ditemukan dalam "Madu Lomuq" yang mengungkapkan cara-cara pengambilan madu. Konsep ekologi Korrie yang tertuang dalam konstruksi arcadia adalah keindahan alam dan kedinamisan masyarakat yang hidup berdampingan dengan lamnya. Selain itu juga ada kerinduan akan keadaan alam sebelum ala menjadi rusak.

Kajian apokaliptik berisikan narasi kepahlawan dapat ditemukan dalam 'Sungai Nyuatan". Narasi kepahlawan tersebut tergambar dalam tokoh Tingang, seorang anak lelaki pemberani yang mampu menangkap buaya dengan panjang tiga meter. Ketram- pilannya dalam mengendalikan sampan yang ditarik buaya, menangkap dan mengikat buaya membutuhkan ketrampilan tersendiri. Konsep ekologi yang ingin diutarakan Korrie melalui tokoh Tingang adalah ketrampilan anak-anak di pedalaman dalam bergumul dengan alam sangatlah tinggi. Selain narasi kepahlawanan, kajian apokaliptik juga mengandung elemen ramalan yang dijumpai dalam "Sungai Nyuatan". Korrie ingin mengungkapkan alam adalah sesuatu yang harus dijaga, kealalian dalam menjaga alam menyebabkan hilangnya suatu ekologi.

Kajian etika lingkungan yang dapat dijumpai dalam "Teluk Par" dan "Madu Lomuq" merupakan kearifan lingkungan dalam menjaga lingkungan di Teluk Par dan mengambil madu dengan cara-cara yang bersahabat dengan alam.

\section{DAFTAR PUSTAKA}

Ammar, Akbra Fauzi. 2014. Kritik Ekologi dalam Kumpulan Cerpen Kayu Naga Karya Korrie Layun Rampan melalui Pendekatan Ekokritik. Yogyakarta: UNY.

Amrih, Pitoyo. 2008. Ilmu Kearifan Jawa. Yogyakarta: Pinus Book.

Buell, Lawrence. 1995. The Environmental Imagination. Cambridge: Harvard University Press.

Endraswara. 2016. Teori Kajian Sastra Ekologis. Dalam Endraswara (Ed). Sastra Ekologis, Teori dan Praktik Pengkajian. 1--17. Jakarta: CAPS.

Djuweng, Stepanus. 2008. Tradisi Lisan Dayak dan Modernisasi Refleksi Metodologis Penelitian Sosial Positif dan Penelitian Partisipan Dalam Pudentia (Ed). Metodologi Tradisi Lisan. 157--182. Jakarta:ATL.

Garrad,Greg. 2004. Ecocriticsm. NewYork: Routledge.

Kaplan, David dan Roberts A. Manners. 2012. Teori Budaya. Pustaka Pelajar: Yogyakarta. 
Putri, N . Q. H, Nisa Fitriyani Afifah, Hasrul Rahman. 2019. Kearifan Lingkungan Masyarakat Dayak Benuaq dalam Novel Api Awan Asap: Kajian Ekokritik Giiford. Satwika, vol 3 (2019) issue 2, 132-141.

Rampan, Korrie Layun. 2002. Riam Yogyakarta: Gita Nahari.

Ratna, Nyoman Kutha. 2008. Teori, Metode, dan Teknik Penelitian Sastra. Yogyakarta: Pustaka Pelajar.
Rueckert, William. 1996. Literature and Ecology: An Experiment in Ecocritism. Dalam Glotfelty and Fromm (Ed) .The Ecocriticsm Readers: Landmarks in Literary Ecology:105--123. Atlanta: University of Georgia Press.

Sukmawan, Sony. 2016. Ekokritik Sastra Menanggapi Sasmita Arcadia. Malang: UB Press. 